\title{
Hõimlane verejõe tagant: Saami muinaslood tootempõhjapõdrast. IV
}

\section{$\underline{\text { Enn Ernits }}$}

Eelmises numbris kõneks olnud Meandashi kosimislugudes räägiti inimeste moondumisest loomadeks ja nendega abiellumisest, mistõttu pole ehk liiast ülevaade teistestki taolistest saami juttudest. Suuremat huvi võiks pakkuda koerinimese lugu, millel on ühisjooni Meandashi naisevõtmise lugude kolmanda alatüübiga.

\section{Teine ekskurss}

Muud lood abielust loomadega ja nendeks moondumisest

T. I. Itkoneni teatel on saamidel ohtrasti muinaslugusid inimese moondumisest karuks, hundiks, põhjapõdraks, koeraks, kärbiks, linnuks, meriforelliks, hiidlestaks ja siiaks (Qvigstad 1925; Itkonen 1948: 526, 536-537). Üritame kättesaadava kirjanduse vahendusel teha lugeja mõne tüübiga tuttavaks. Alustame koerinimese lugudest, millel saab eristada järgmisi osi:

1) kolme sureliku neiu kosimine,

2) pahategu,

3) lahkumine naise juurest ning

4) oma abikaasa vaevarikas otsimine.

Neist kolm esimest motiivi sarnanevad üldjoontes Meandashi-lugudega. N. Briskin on tundmata vestjalt kirja pannud järgmise sisuga loo (Briskin 1917; 7-9; Kert 1980: 224-228), millest esitan kokkuvõtte:

Taadil-eidel polnud lapsi. Nad soovisid endale kasvõi koerakutsikat. Täiskasvanuks saades hakkas koerinimene jahil käima. Ühel päeval nõudis ta, et vanemad otsiksid talle pruudi. Isa tegi poja tahtmist mööda, kuid järgmisel hommikul leiti tüdruk tapetult. Nii juhtus ka teise neiuga. Naabrid õpetasid nooremat õde, kuidas tuleb koerpeiuga ümber käia (pärast jahilkäiku teda hästi toita ja öösel hellitada). Koerinimene oli päeval koer ja öösel kaunis noormees. Aasta hiljem põletas ämm öösel koerinimese naha ära. Koerinimene põgenes sõnadega: Hüvasti, niipalju te siis mind nägitegi, kui ei osanud minuga elada.

Kahe neiu surma põhjusteks on erinevates teisendites nende negatiivsed isikuomadused:

1) laiskus,

2) hoolimatus ja pahatahtlikkus koerinimese suhtes, mis avaldub selles, et

a) talle ei anta liha, vaid konte,

b) teda nimetatakse (sõimatakse) koeraks,

c) teda ei hellitata öösel.

Koerinimese lugu on talletatud nii koltadelt, kildinitelt kui ka turjalastelt (Itkonen 1931-1936: 170175, 194-202; Jermolov 1959: 67-69; Kert 1980: 224-234; Itkonen 1985: 95-101). Laia leviku üheks põhjuseks võib olla genuiinse tootemiloo liitumine rahvusvahelise muinasjututüübiga. 
Enamik koerinimese-lugusid sisaldab abikaasa kolm aastat kestvat tagaotsimist. Nahapõletamise motiivist (vt XIV jutt) algabki rahvusvaheline imemuinasjutt vaevarikkast otsimisreisist, mille käigus kulub kolm paari raudkingi ja kolm raudsaua ning suus sulab kolm metallnööpi. Lugu nimetatakse sageli muinasjutuks I(mei)lusast Katerinast. Nii kutsuti uut neiut, kellega koerinimene oli vahepeal abiellunud.

1929. aastal pani V. Tsharnoluski ühelt Kintushi vestjalt kirja põneva loo abielust kaarnaga (Tsharnoluski 1962: 278-290). Teeme sellestki kokkuvõtte:

Kaarnad nõudsid surma ähvardusel mõistatusliku vesise soo peal, et vend annaks neile järjepanu oma kolm õde naiseks. Vend nõustuski. Mure tõttu lahkus ta üksikuna isakodust laia ilma rändama. Äkki kutsus kaaren ta oma perele külla. Vanema õe juurest sõideti keskmise ja seejärel noorema juurde; need elasid vastavalt vaskses, hõbedases ja kuldses majas. Kõikjal võtsid venda vastu hästi rõivastatud õde, inimeseks moondunud kaaren ja mängivad lapsed. Vend kurvastas, et ainult tema on vallaline, läks taas mööda ilma rändama ning sattus metshaldja juurde. Viimane hoidis vangis neidu, kelle kolm venda elasid kuskil metsas pistrikutena. Üksik vend otsis pistrikud üles. Need varustasid ka nukra venna tiibadega, mispeale lennati metshaldja juurde ja vabastati õde vangistusest. Seejärel vend kihlus pistrikute õega. Noorpaarile ehitati klaasist maja. Ka vennadpistrikud abiellusid. Kaarnate elamute vahele püstitati veel üks klaasmaja. Nii sai alguse uus küla.

Loo lõpp kujutab endast suhteliselt hilist etioloogilist lisandust. Siinkirjutajale pole kahjuks teada teisi variante, seepärast ei oska ta otsustada loo autentsuse üle. Kui see on rahvaehtne jutt, siis võib ta väljendada mitme tootemi vahelist abielu. Jutust ilmneb konflikt venna ja metsa(haldja) vahel; see võib tähendada konflikti lageda ja metsase ala elanike vahel. Huvi pakub teispoolse maailma asumine soo keskel (vrd I jutt).

V. Tsharnoluski (1962: 187-190) on avaldanud Jovkõist noteeritud jutu "Topeltpäike", milles väljendub taassünni idee: kõneldakse saami muutumisest haugiks eesmärgiga sattuda mõne noore neiu üssa, sündimaks uuesti siia ilma. Muide ühes inarisaami loos jutustatakse koltaga abiellunud naisest, kes muutis enda siiaks, sattus siis kalameeste kätte ja moondus taas inimeseks (Koskimies, Itkonen 1978: 252-253). Sellega on sündmustiku poolest väga sarnane teisend, milles taat moondus iheruseks (Itkonen 1931: 74-75).

Rikkalikult näiteid leidub inimese moondumisest karuks, seda eriti koltadel. Ühes loos jutustatakse, kuidas Audne mees Irjan viibis kahel korral teadmata kus. Pere otsis teda, kuid ei leidnud üles. Kolmandal korral läks Audne oma mehele jälgi pidi järele, kuid märkas peagi lumel karu jälgi. Naine astus jälgi mööda edasi ning muutus karuks. Ta sai oma mehega kokku. Irjan õpetas, kuidas toimida, kui lapsed tulevad neile järele. Poeg Hendo tappis isa noolega, nülgis naha ja laotas selle maa peale. Ema tormas koopast välja, heitis naha peale ning muutus taas inimeseks, kuid tal jäi alles karu käpp, sest teine jalg ei sattunud nahale (Ostrovski 1889: 328-329). Sarnaseid kirjapanekuid on avaldatud veel teisigi (Itkonen 1948: 364, 526; Jermolov 1959: 61-62; Tsharnoluski 1962: 176-177;

Koskimies \& Itkonen 1978: 254-256; Szabò 1967: 76--77, 86--89, 132--133; rohkeid kirjandusviiteid sisaldab Itkonen 1948). Inari saamide teatel pidasid koltad karu oma hõimlaseks; seepärast ei söödud selle uluki liha, küll aga tarvitati nahka (Paulaharju 1921: 72).

Analoogiliselt moondusid kolta jutus kolm kaupmeest karudeks. Üks neist uppus järve. Poisid nülgisid tal naha maha, mille all nähti ehisvööd rahadega. Poisid oletasid, et karud olid varemalt inimesed (Itkonen 1931: 72-74). Karuinimese-lugude hulka kuulub ka tsükkel rumalavõitu Taalost, kes röövib endale saami tüdrukuid naiseks ja teeb muid pahategusid. 
Saamidel on veel arvukalt lugusid abiellumisest paha konnalaadse olendiga. Hundiks moondati inimesi varastamise ja muude kuritegude pärast. Ühes üldtuntud loomamuinasjutus oli rebasel sureliku eide-taadi tütar naiseks (Itkonen 1948: 551).

Moondamisvõimet evisid suured nõiad. Näiteks Soomes jutustati kahest Teno jõe ääres elanud mehest Paavush-Niilast ja Piihtushist, kes võisid moonduda nii põhjapõdraks, hundiks, kärbiks, pardiks, haneks, kotkaks, haugiks, ahvenaks, ja isegi lihakärbseks (Itkonen 1948: 536-537; Itkonen 1960).

Ent jäägu saami loomalugude põhjalikum analüüs tulevikuks.

\section{Kokkuvõtvalt naimislugudest}

Naimislugude kokkuvõte olgu esitatud alatüüpide kaupa. Esimese alatüübi jutte on talletatud kolm, millest üks on liiga lühike ja katkendlik järelduste tegemiseks, mistõttu saame arvestada vaid kahe Imandra äärest noteeritud teisendiga, mille jutustaja täpsem hõimukuuluvus jääb teadmata. Mõlemad variandid on ülesehituse poolest üsna sarnased (tabel 5). Neis võib eristada nelja osa:

1. põhjapõdrakoja ehitamine,

2. naisevõtt,

3. taaditütarde käitumine ja

4. nende saatus.

Kaht tütart tabab nende ebasobiva iseloomu tõttu surm, kolmas saab põhjapõdra naiseks. Kõigis teisendites (ka fragmentaarses kolmandas) esineb universumisfääre eristav verejõgi, mille ületamiseks on vajalik loitsimisoskus. Jõest, mis leppa närides kuivaks muutub, kõneldakse veel ühes kolta koerinimese loos (Itkonen 1931: 171-173).

Kuuendas jutus puudub vaid kojaehitamise motiiv, mis seondub noore põhjapõdra perekonnaelu alustamisega; lesel on eluase olemas. Asjaomane motiiv esineb ka kahes teise alatüüpi kuuluvas kildini (IX, X) loos ning poja soovina ühes kildini loos. Seepärast pole välistatud, et kõik naisevõtulugude esimese alatüübi jutud on talletatud üksnes kildinitelt. Selle kasuks kõneleb ka kolmas, katkendvariant, mis on kirja pandud alles 1990-ndatel aastatel.

\begin{tabular}{|l|l|l|}
\hline Motiiv & I jutt & VI jutt \\
\hline Koja ehitamine & + & - \\
\hline Naisevõtt & Ema naitis & Leskpõder nais ise \\
\hline Verejõgi & + & + \\
\hline $\begin{array}{l}\text { Vanemate } \\
\text { tütarde } \\
\text { käitumine }\end{array}$ & $\begin{array}{l}\text { Kuivatasid } \\
\text { jalanõusid halvasti; peksid } \\
\text { Meandashi õdesid-vendi }\end{array}$ & $\begin{array}{l}\text { lapsi; } \\
\text { lasksid lastel asemed täis } \\
\text { pissida }\end{array}$ \\
\hline $\begin{array}{l}\text { Vanemate } \\
\text { tütarde saatus }\end{array}$ & Muudeti kivideks & Pusiti surnuks \\
\hline
\end{tabular}




\begin{tabular}{||l||l||l||}
\hline $\begin{array}{l}\text { Noorema tütre } \\
\text { käitumine }\end{array}$ & $\begin{array}{l}\text { Kuivatas jalanõud hoolikalt; } \\
\text { hellitas Meandashi õdesid- } \\
\text { vendi, punus neile pärjad } \\
\text { sarvedesse }\end{array}$ & $\begin{array}{l}\text { Hellitas põhjapõdra lapsi, } \\
\text { punus lilled sarvedesse; } \\
\text { hooldas lasteasemeid }\end{array}$ \\
\hline $\begin{array}{l}\text { Noorema tütre } \\
\text { saatus }\end{array}$ & Sai Meandashi naiseks & Sai Meandashi naiseks \\
\hline
\end{tabular}

Tabel 5. Esimese alatüübi motiivid varianditi.

Kummagi teisendi põhiliseks erinevuseks on asjaolu, et:

1. ühel juhul on põhjapõder ise lesk ja otsib naist, kuid teises variandis naib ema pojale naise,

2. ühel juhul pusitakse ebasobivad naisekandidaadid surnuks, teisel aga muudetakse nad kiviks ning

3. vanemad tütred ei hoolda laste asemeid.

Õigupoolest on viimane tõik laenatud lahkumisloost.

Esimese alatüübi ideaalvarianti võiks ehk kujutada järgmiselt: Põderinimese ema või ta ise kosis verejõe tagant surelike perekonnast järjepanu vanema, keskmise ja noorema tütre. Kaks esimest tütart olid sõnakuulmatud ja pahatahtlikud ning vihkasid ka lapsi. Mõlemad tütred mõisteti surma. Põderinimene abiellus hoolsa, sõnakuuleliku noorema tütrega.

Teist alatüüpi on teadupoolest talletatud suhteliselt rohkem kui esimest ja kolmandat, sh Aahkkelist üks, kildinitelt kolm ja turjalastelt kuus teisendit. Ühe muinasloo päritolu pole teada. Peale muu on viimane ebatäielik, sest pole käsitletud, kes kelle kosis, midagi pole jutustatud tütarde käekäigust. Üks seni tundmatuks peetud jutt osutus, nagu eespool viidatud, teistmoodi kirjanduslikult töödeldud variandiks.

Selle alatüübi lugudes saab eraldada kaht osa:

1. kolm kosilast ja

2. vanemate külaskäik oma tütarde juurde.

Aahkkeli ja kildini lugudes on kosimist käsitletud suhteliselt lühidalt (tabel 6). Konflikt eri tootemist põlvnevate vanemate vahel võib olla V. Tsharnoluski fabritseeritud. Unenäo-motiivi teistes juttudes ei esine. Nii kildini kui ka turja lugudele on iseloomulik peigmehi kirjeldada teatud kehaosade järgi (pars pro toto). XIV loos ilmneb imemuinasjutu mõju. Väga omapärane on XV jutt. Kahjuks ei võimalda tähtsamate iseärasuste ainulaadsus, samuti V. Tsharnoluski võimalikud "täiendused" olulisi järeldusi teha lugude ja motiivide päritolu kohta. Mitmes turja loos käsib isa peigmehi valida; nii ka tundmatu päritoluga kaheksateistkümnendas jutus.

Tundub, et turjalastel oli levinud kaks kosimimislugude liiki: ühtedes tulevad kosilased vanematekoju ja neile antakse naiseks järjekorras vanem, keskmine ja noorem tütar, teistes aga lastakse tütardel kindlate reeglite alusel abikaasa ise valida. Paaris loos ilmneb olulisi unustamisjälgi. 
Seega võiks kosjaskäigu teemal koostada kaks ideaalvarianti:

1. Taadil(-eidel) oli kolm tütart. Kaareninimene kosis vanema, hüljesinimene keskmise, põhjapõderinimene noorema tütre. Tütred viidi peigmehe koju.

2. Taadil(-eidel) oli kolm tütart. Tütardele oli tehtud ülesandeks kindla korra järgi mehele minna. Saabusid kolm kosilast (kaareninimene, hüljesinimene ja põhjapõderinimene) või läksid tütred neid ise otsima. Tütred abiellusid väljavalitutega.

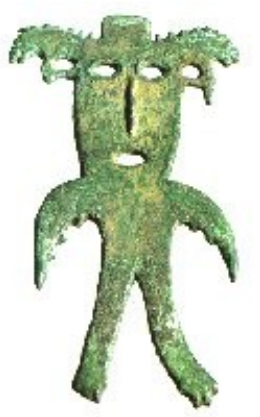

Noorpaari külastas enamates lugudes taat (7 teisendit) ning tunduvalt harvem taati-eite üheskoos (4 teisendit) (tabel 7). Omapärane on XV jutt, kus taat käis iga tütre külastamise järel taas kodus. Kaheksal juhul nenditi, et kaht vanemat tütart on väimees vigastanud, ühel juhul mainiti vaid kaarna naist, kahel juhul on vigastused jäetud mainimata.

Kogu Koolas kirjeldati taadi-eide esimese külaskäigu ajal lastelapsi, kel leidus kindlasti zoomorfseid jooni, suhteliselt ühelaadselt; detaile on mõnikord unustatud, eriti XVIII jutus. Kahes loos ei tehta koja läheduses viibivatest lastelastest juttu.

Vanemad sõid tavaliselt tütre peres. Seda pole märgitud vaid XIII loos. Ideaalvariandile vastab söökide kirjelduse poolest IX jutt. Rahvajuttudele tüüpiliselt on mõne külaskäigu puhul söömine mainimata jäänud või on piirdutud üldiste väljenditega, nagu söödi või söödi-joodi.

\begin{tabular}{|l|l|}
\hline $\begin{array}{l}\text { Jutu number } \\
\text { ja päritolu }\end{array}$ & Iseärasused ja ühisjooned \\
\hline 8. ${ }^{*}$ Aahkkel & Kosimisest lühidalt; konflikt eri päritoluga vanemate vahel. \\
\hline 9. Kildin & Kosimisest lühidalt. \\
\hline 10. - " - & $\begin{array}{l}\text { Kosimisest lühidalt; eide unenägu: hülge loivad, kaarna nokk, } \\
\text { põhjapõdra sõrad; tütred olid äkki mehele läinud. }\end{array}$ \\
\hline 11. Turja & $\begin{array}{l}\text { Eide sõnad hommikul: kaarna tiivad on konksus, hülge jalad } \\
\text { on siruli, sarva sarved ripuvad. }\end{array}$ \\
\hline 12. ${ }^{*}$ - " - & $\begin{array}{l}\text { Tuletegemine; eide sõnad hommikul: mees süsimustade } \\
\text { kaarnatiibadega, merelooma loivad paistavad, põhjapõdra } \\
\text { sarved toretsevad. }\end{array}$ \\
\hline 13. ${ }^{*}$ - " - & $\begin{array}{l}\text { Kosimisest pikalt; tuletegemine; eide sõnad hommikul: kaarna } \\
\text { tiivad paistavad, hülge loivad kraabivad, põhjapõdra sarved } \\
\text { näha. }\end{array}$ \\
\hline 14. - " - & $\begin{array}{l}\text { Kolm peigmeest ilmusid korraga; taat laskis neil kapad } \\
\text { valmistada. }\end{array}$ \\
\hline \hline 15. - " - & $\begin{array}{l}\text { Kosimisest pikalt ja omapäraselt; pulmad; noorpaar lahkus } \\
\text { järgmisel hommikul; eide sõnad: pea tolkneb nagu kaarnal, } \\
\text { justkui hülge loivad välja sirutatud, tolknevad nagu sarved. }\end{array}$ \\
\hline
\end{tabular}




\begin{tabular}{||l|l|}
\hline 16. - " - & $\begin{array}{l}\text { Kolm peigmeest ilmusid korraga; taat käskis tütardel } \\
\text { saabunud peigmeeste seast õige valida. }\end{array}$ \\
\hline 18. Teadmata & $\begin{array}{l}\text { Taat käskis tütardel minna merekaldale ja seal esimese } \\
\text { vastutulijaga abielluda. }\end{array}$ \\
\hline 19. Kildin & $\begin{array}{l}\text { Kosimisest lühidalt; tuletegemine; kaarnatiivad räpna kohal, } \\
\text { põhjapõdra sarved räpna kohal }\end{array}$ \\
\hline
\end{tabular}

Tabel 6. Kolm kosilast varianditi (tärniga on tähistatud V. Tsharnoluski kirjapanekud).

Külaskäigule järgnenut või selle lõppu ei ole näidatud ühes kildini loos, kahel juhul - kumbki, eriti kaheksateistkümnes jutt on viletsasti säilinud teisend - jääb taat noorema tütre juurde üksnes ööseks. Võib arvata, et algsem oli sinna elamajäämine. Neljal juhul tulid võõrsilkäijad koju, viiel juhul jäädi noorema tütre juurde elama. V. Tsharnoluski kirjapanekud võõrsilkäigu kohta näivad olevat üldiselt usutavad. Teistes lugudes peale kaheteistkümnenda ja üheksateistkümnenda pole teateid varanatukese äratoomise kohta kodust, kuid olgu pealegi.

\begin{tabular}{|c|c|c|c|}
\hline $\begin{array}{l}\text { Jutu } \\
\text { number ja } \\
\text { päritolu }\end{array}$ & $\begin{array}{l}\text { Külastas: taat }(T), \\
\text { eit }(\mathrm{E}) ; \text { hilisemad } \\
\text { sündmused }\end{array}$ & $\begin{array}{l}\text { Vigastatud } \\
\text { silmad (S), käsi } \\
(\mathrm{K})\end{array}$ & $\begin{array}{l}\text { Söök/söömine kaarnal } \\
\text { (K), hülgel (H), } \\
\text { põhjapõdral (P) }\end{array}$ \\
\hline 8. Aahkkel & $\begin{array}{l}\text { T; tõi ka E tütre } \\
\text { juurde }\end{array}$ & $\mathrm{S}, \mathrm{K}$ & $\begin{array}{l}\text { K: jäänused, H: } \\
\text { loomaliha ja rasv, P: } \\
\text { värske liha, peen rasv }\end{array}$ \\
\hline 9. Kildin & $\mathrm{T}$; koos tütrega koju & - & $\begin{array}{l}\text { K: kõhukelme, } \\
\text { saapapealsed, H: } \\
\text { kalajäänused, P: } \\
\text { liharoad }\end{array}$ \\
\hline 10. - " - & $\mathrm{T}, \mathrm{E}$; hiljem koju & S, K & K: -; H, P: söödi \\
\hline 11. Turja & $\mathrm{T}$; hiljem koju & $\mathrm{S}, \mathrm{K}$ & $\begin{array}{l}\mathrm{K}, \mathrm{H}: \text {-; P: palju sööki } \\
\text { anti kaasa }\end{array}$ \\
\hline $12 .^{*}-"-$ & $\begin{array}{l}\text { T, E; T tõi kodunt } \\
\text { vara tütre poole; } \\
\text { jäid sinna elama }\end{array}$ & $\mathrm{S}, \mathrm{K}$ & K, H, P: söödi \\
\hline $13 .^{*}-"-$ & $\begin{array}{l}\text { T, E; jäid sinna } \\
\text { elama }\end{array}$ & $\mathrm{S}, \mathrm{K}$ & - \\
\hline 14. - " - & T; jäi sinna ööseks & S, K & P: lihapekk, üdi \\
\hline 15. - " - & $\begin{array}{l}\text { T; T tõi ka E tütre } \\
\text { juurde }\end{array}$ & $\mathrm{S}$ & K, P: söödi, H: kalaroad \\
\hline 16. - " - & $\mathrm{T}$; hiljem koju & $\mathrm{S}, \mathrm{K}$ & $\begin{array}{l}\text { K, H: söödi, P: kala, } \\
\text { liha }\end{array}$ \\
\hline
\end{tabular}




\begin{tabular}{||l|l||l||l||} 
18. Teadmata & T; jäi sinna ööseks & - & K, H: söödi, P: - \\
\hline \multirow{2}{*}{ 19. Kildin } & $\begin{array}{l}\text { E, T; T tõi kodunt } \\
\text { vara tütre poole; } \\
\text { jäid sinna elama }\end{array}$ & S, K & $\begin{array}{l}\text { K: lõunasöögi ülejääk, } \\
\text { H: kala, P: liha }\end{array}$ \\
\hline
\end{tabular}

Tabel 7. Vanemate külaskäik varianditi (tärniga on tähistatud V. Tsharnoluski kirjapanekud).

Külaskäigu ideaalkuju võiks olla järgmine: Taat üksi või koos eidega külastasid järjest oma tütreid. Vanemal tütrel oli kaareninimene silma peast välja nokkinud. Lapsed lendlesid koja kohal. Seal söödi lihajäänuseid, kelmeid jms. Kaareninimese juurest mindi hüljesinimese juurde, kus lapsed lasksid koja pealt liugu. Keskmisel tütrel oli käsi ära näritud ning seal söödi ainult kala(jäänuseid). Mindi põhjapõderinimesele külla. Seal mängisid lapsed kas lihtsalt sarvedega või erilist sarvemängu. Noorema tütre elu oli korras. Söödi lihatoite. Jäädi elama noorema tütre juurde.

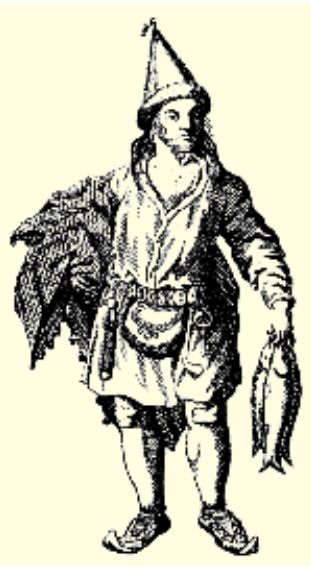

Kolmanda alatüübi lugudes eristuvad kolm osa:

1. naisevõtt,

2. tütarde käitumine ja

3. nende saatus.

Sarnasus esimese alatüübiga on märkimisväärne ning põhilised erinevused viimasest on järgmised:

1. ei tehta juttu põhjapõdrakoja ehitamisest ja

2. süüteod on erinevad, kuigi neidki võib taandada sõnakuulmatusele ja kurjusele.

Kolmandast alatüübist on avaldatud kaks juttu. Kahekümnes lugu on põimunud koerinimese looga. Esimeses loos muutis ema mõlemad miniakandidaadid kiviks, teises loos puskis põhjapõder keskmine tütre surnuks.

Kolmanda alatüübi ideaalkuju võiks olla ligikaudselt järgmine: põhjapõderinimesele naiti algul surelike perekonnast vanem, siis keskmine ja lõpuks noorem tütar. Vanem ja keskmine tütar ei käitunud nii nagu vaja, rikkudes eelkõige lihakeetmise tabu. Nad mõisteti surma. Põhjapõderinimene abiellus noorema tütrega, kes oli sõnakuulelik.

Täpsemaid järeldusi võimaldab loodetavasti lahkumisloo analüüsimine.

\subsubsection{LAHKUMINE NAISE JUUREST}

Üks ajajärk Meandashi elust oli möödunud ja ta lahkus oma naise juurest. Lahkumislugu koosneb vähemalt kahest lülist:

1. pahateost, mis koosneb omakorda kahest alaosast

a) põhjapõdra hoiatusest ja

b) pahateost endast, 
2. pahateost põhjustatud põgenemisest kodust ja

3. ema reageeringust sellele.

Teisendites on tavaliselt vaid väiksemaid erinevusi.

Laste asemele pissimine oli pahategu, millest sugenes kojas paha lõhn, mida põhjapõdrast isa ei suutnud taluda. Arvatavasti seletub see jahimeeste praktikaga, mis nõuab, et nad oleksid äärmiselt puhtad, kuna loomadel on haruldaselt hea lõhnatundmine. Müütilises mõttes oli tegu jahitabuga. Jahileminekule eelneval õhtul pesi kütt end korralikult, ei maganud naise kõrval, vaid väljaspool koda ning pani järgmisel hommikul selga hästituulutatud rõivad (Tsharnoluski 1966: 303).

Meandashi-müüdis ei saanud abikaasast põhjapõder paha lõhna tõttu muutuda enam inimeseks; ta põgenes kodust, laps(ed) kannul. See oli teine põgenemine, teistkordne piiriületamine, sest esimest korda pageti ju lapsepõlvekodust. Põgenemismotiiv võimaldas põhjendada,

1. miks põhjapõdrad ei ela enam koos inimestega ning

2. kuidas metsikust põhjapõdrast sai saamide peamine elatusallikas.

Seega on üheaegselt tegu ka seletusmüüdiga.

Sündmuste taolisest käigust oli ema muidugi rabatud. Ta käitumine erines eri teisendites: mõnes loos ta soovis lastele head, teises ähvardas, kolmandas aga jooksis oma pereliikmetele järele. Kuna lugudes esineb kahe põgenemise (ema juurest ja naise juurest) kontaminatsiooni, siis käsitleb siinkirjutaja uuesti ka esimese põgenemise lugusid, sest ema reaktsioon on mõlemal puhul ühesugune.

Esimene jutt (kokkuvõte vt 4.1.1)

Jätkame nüüd V. Tsharnoluski vahendusel P. Sarvanovi juttu, milles võib eristada eespool mainitud kolme põhimotiivi:

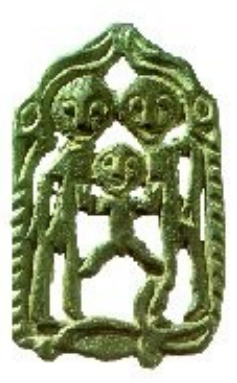

Meandash-poeg hakkaski elama koos inimesetütrega. ;Nad elasid hästi. Naine hoidis teda, kuid mees oli karm. Ta manitses naist:

"Laste asemetele ei tohi kuseseid nahku jätta."

Neil oli palju lapsi, seepärast ka palju asemeid. Vaat elavad

koos. Nad elavad väga hästi. Kord ei vaadanud naine

järele: poisike oli aseme märjaks teinud.

Meandash naasis jahilt, astus kotta. Ta ei jõudnud veel inimeseks moonduda, kui ukselt lõi ropp hais ninna. Ta aevastas korra ja ütles oma naisele Meandash-koabile:

"Ma ju hoiatasin sind, et ei tohi lasta aset märjaks teha, kuid nüüd on see märg - ajab paha lõhna! Ma ei suuda siin enam elada! Raske lehk rõhub mu kõrvu, sellest on keha hakanud võbisema ja värisema."

Meandash pages oma ema juurde. Tuli ema juurde ja lausus: "Emake, ma ei suuda enam temaga koos elada! Raske lehk hakkas kõrvu rõhuma."

Ema vastas: "Ma ju ütlesin sulle! Meandashite poeg ei saa elada koos inimesenaisega. Kuule, laps, naase meandashite koju. Näh, siin on sulle ema rind. Näh üks tiss... ja teine... ja kolmas... ja neljas tiss. Ela hästi! Kuid, pojake, hoia end selle eest, kel on musta karva nahk karuelukat karda! Hoia end hundieluka eest ning pelga puu ja kivi tagant hiilivat punanäolist inimest."

Seda öeldes moondus Meandash-neiu Koannt-akkaks*22 ning kutsus kõik põhjapõdravasikad meandashi-kojast välja. Meandash-koab, Meandash-paarrni naine, tõmmanud endale pahalõhnalise, läbiligunenud asemenaha keha ümber, jooksis põdralehmaks moondununa 
neile järele. Temast sai põhjapõtrade juhtloom. Ta oli nagu kaela pandud kelluke nende kutsumiseks.

Ennäe, ta laotas me tundrutesse ja lambide äärde musttuhat põhjapõdrakarja.

Selle loo üheks iseärasuseks on see, et Meandash läks ema juurde kurtma oma saatust. Tissi pakkumine esineb küll mitmes teisendis, kuid käesoleval juhul on jutustaja tõenäoliselt vääratanud. Rinda pakkus neil puhkudel Meandashi naine oma lapsele. P. Sarvanovi loos tehakse juttu põhjapõdraema neljast nisast. Ka hoiatusi lausutakse teistes variantides Meandashi pojale.

Huvipakkuv on muinasloo lõpuosas leiduv müüdi seletus ning asjaolu, et Meandashi abikaasa pani endale kusese naha ümber ja muutus põhjapõtrade haldjaks, kellest sõltus loomade paljunemine ning viimasest ka saamide elu. V. Petruhhin on väitnud, et naine on olnud vahendajaks kütihõimu ja loomariigi vahel, kusjuures arenenud mütoloogias sai temast harilikult loomade haldjas (Petruhhin 1986: 5). Nii näikse olevat see ka käesolevas loos. Kui märjakstehtud nahka riietumine pole juhuslik, siis võib ta seonduda ehk viljakuskujutelmaga. Kõrvutamiseks annab alust müüt Meandash-põõrrest, kes urineerides muutis paikkonna viljakaks (vt Mäetagused, nr 4, lk 42).

Selles versioonis on toimunud kontaminatsioon saami põhjapõdrahaldja kujutelmaga. Kirjanduse andmeil on nimetatud funktsioonis tundrus rikkalike samblikuväljade keskel elav Luot-Hozik, kes kaitseb saamide uskumustes kodustatud põhjapõtru ja saadab küti püssikuuli ette metsikuid. Teda kirjeldatakse nii: Käib jalgadel nagu inimene, ka inimese näoga, kuid on üleni karvane, nagu põhjapõder (Haruzin 1890: 152).

T. Itkonen on koltadel maininud analoogilist olendit, nimelt antropomorfset, kuid karvast miehttshozjen'i (saami 'metshaldjas'), kes kaitsvat kodustatud põhjapõtru (Itkonen 1945/1946: 129).

Teine jutt (kokkuvõte vt 4.1.1)

See jutt kõneleb esimesest põgenemisest. Ema tahtis pojale tissi anda, kuid see keeldus.

Kolmas jutt (kokkuvõte vt 4.1.1)

Selles kildini loos keelas põhjapõder oma naisel riputada täispissitud nahka kuivama koja tuulepoolsele küljele. Ometi ei pidanud naine keelust kinni. Põhjapõder pani plehku, poeg kannul. Ema keelituste ja tissipakkumise peale vastas poeg jämedalt:

Mul pole vaja ei su üht ega teist tissi. Sulle jääb pissi täis häbe ja pissi täis nahk. Jooksen sinna, kuhu läks minu isa.

Selline vastus on ainulaadne. Ema heasoovlikkuse tõttu poeg leebus ja soovis:

Jää terveks, ema. Metsiku põhjapõdra jalg saagu sulle lihapakuks ja reieluu su ahju põhipalgiks. 
Seda soovi ei esine teistes variantides. Siingi väljendub teatavasti põdrakoja motiiv, kuid teisenenud kujul.

Ema õpetussõnad kõlasid järgmiselt:

Sa pead kartma iga lehte ja iga põõsast ning pead vaatama järele, kus ja millise põõsa taga piilub sind inimeselaps. Ja kui sa teda ka näed, siis ära karda enne, kui oled tuule käes lõhna järgi ta jälgedele sattunud.

Neljas jutt (kokkuvõte vt 4.1.1)

Asjaomases turja jutus kõneldakse esimesest põgenemisest, millega kaasnes ema needus: kuuli eest sa ei pääse. See põhjendab põhjapõdrajahi teket (müüdi seletus). Püssikuulid on käesoleva aastatuhande leiutis, ent pole välistatud, et muiste kõneldi nooltest.

Viies jutt (kokkuvõte vt 4.1.1)

Tavaliselt põgenes põhjapõder inimnaise juurest üks või mitu last kannul, kuid selles variandis on jutustaja liitnud kaks lahkumistüüpi, nimelt emakodust lahkumise ning põgenemise naise juurest. Seepärast on siia vahele kiilutud ka ema abistamise ja oma päritolu väljapinnimise motiiv.

Ema õpetussõnadel on käesolevas teisendis järgmine kuju:

Kui näed loamättaid kõrgumas, siis pead sa neid pelgama. Need on kütid, kes varitsevad. Kui kuuled mingit krabinat, siis pead sa seda kartma. Kui näed soos pöörlevaid mättaid, siis neid pole sul vaja peljata. Need on naised (marju korjamas).

Kuues jutt (kokkuvõte vt 4.1.2.1.1)

Selles möödunud sajandil Imandra kandis kuuldud loos soovitas ema hoiduda kavala laplase eest. Selle kõrval leidub usundiloolasele huvipakkuv detail: tubli kütt võib lasta endal sarvega südamesse torgata. Siinpuhul peetakse silmas vist põhjapõdrahõimu kütte, kes on ise pooleldi põdrad. Soovitusest ilmneb püüd eristada tõelisi jahimehi muiduküttidest.

Kaheksas jutt (kokkuvõte vt 4.1.2.1.2)

See on iseenesest küllaltki tüüpiline, kuid üsna pikk lugu, mis on üles kirjutatud Aahkkeli kandis. Jutus leidub ka müüdi seletus, miks põhjapõdrad elavad inimestest lahus:

Tollest ajast peale elavad metsikud põhjapõdrad meist, inimestest eraldi ning inimesed eraldi metsikuist põhjapõtradest. Aga varem olid ühes põdrad ja inimesed, nagu vennad ühest sugupõlvest. 
Eespool käsitletust ilmneb, et kaheksas jutt kattub põhiliselt seitsmeteistkümnenda looga, mille iseärasused on, et Meandash käskis täispissitud nahad heita jõkke või ojja, mitte aga kojas hoida, õhu käes kuivatada, uksele riputada. Loos keelas abikaasa nahkade kuivatamise päikese käes, mida jutuvestja kommenteerib:

Kojas peab olema alati värsket tuult, nagu vabaduses, avaras tundras. Kui kojas nahk haiseb vängelt, kuidas ta sel juhul jahile läheb. Temast tuleb siis samuti tugevat lõhna-tundes seda, põgenevad tema eest kõik loomad.

Lisaks on vahele kiilutud tütre jutt, milles ta teatab eidele marjuleminekust ning kordab Meandashi käske-keelde. On lisatud väide, et Meandash ei suuda paha lõhna tõttu inimeseks muutuda. Seitsmeteistkümnendas jutus ei käsitleta ema poolt noorima poja kutsumist enne seletust, miks põhjapõdrad elavad inimesest lahus. Kaheksandas loos kõlab see järgmiselt:

Ning jooksevad tema juurest minema ta lapsed, pageb tema juurest ka kõige väiksem neist. Ema hõikab pisikesele, kutsub kõige väiksemat enda juurde:

"Lippa, mu pisike, lippa ema juurde. Emal on piim, emal on soe rind, lippa minu juurde, mu armas lapsuke, lippa minu põlvele."

Vastab talle väike põdravasikas:

"Ei saa, ema, naasta sinu juurde, ei saa tulla, ma lippan isa järel, oma vendade kannul.

Palavik sarvedes haarab mind kaasa ning jooksmine vabaduses on nüüd minu rõõm."

Ning jooksis minema.

V. Tsharnoluski sõnutsi väitis Aahkkeli loo jutustaja

Mihhail Maksimovitsh meandashitest metsikute põhjapõtrade karja nähes:

Need ei ole meandashid. Need on metsikud põhjapõdrad. Tõelised meandashid elavad kõrgel mäel, seal, lääne pool. Seal on neil kõrge mäetipp,

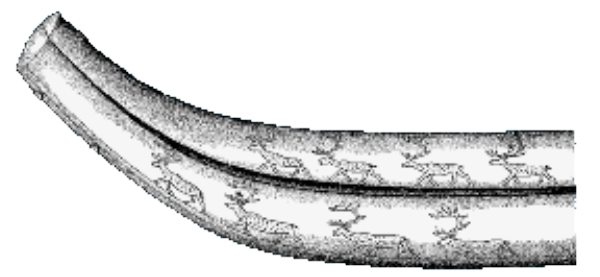
seal neil seisab maja. Nad elavad selles ja näevad kõike, mida tehakse mäe all, allpool: kes kõnnib, kes jookseb ... Kõike näevad nad, kõike teavad ... Kuid meandasheid ei näe keegi ning keegi ei tea, kus neid võib leida. Neile on ohtlik silma vaadata -- jääd pimedaks ja mõistus tumeneb. (Tsharnoluski 1972: 117).

Selgesti väljendatakse ideed, et meandashid on nähtamatud, sest nad pole siitilma elanikud; nende maailm on paigutatud vertikaalse maailma käsitluse kohaselt kõrgele. Mütoloogias võib nii mägi kui ka puu sümboliseerida maailmatelge. Pimedaksjäämisest tuleb meil juttu hiljem.

\section{Üheksas jutt (kokkuvõte vt 4.1.2.1.2)}

Selle suhteliselt pika kildini loo lõpuosas ilmneb unustamise märke. Tavaliselt tehakse juttu asememärgamisest laste poolt, kuid käesolevas jutus pandi päikese kätte kuivama taadi rikutud asemenahk. Tähelepanu vääriv põhjapõdrakoja motiiv seondub enamasti abiellumislooga. Ema elamaasumist taadikoju ei esine teistes tuntud lugudes. 
Kujukalt on kirjeldatud põhjapõdra käitumist kuivavat aset silmates:

Äkki tuleb metsik põhjapõder. Jooksis, jooksis, näeb, et ase kuivab, teab, tähendab, et taat on saabunud ja aseme märjaks teinud.

Ta sööstis vastutuult, tundis järsku lõhna -- ent see on inimeselõhn. Ta jooksis eemale ja

hüppas, sõjakalt sõrgu kopsides oma laste poole: "Mu lapsekesed, tulge minu järel,

inimeselõhn on väga vänge. Ei osanud ema juиa ja süüa [anda], las ta siis istub oma (teo)

jälgedel."

Viimane lause vajab kommenteerimist. Enne asjaomast katkendit kõneldakse loos, et taat oli söönud liiga palju liha ja rasva, mistõttu ei saanud magada, vaid vähkres asemel ja urineeris sellele. Seega viitas põhjapõder liigsele lihasöömisele. Ta süüdistas oma naist äia üleliia söötmises. Liiati oli põhjapõder varem hoiatanud, et taati ei tohi panna magama metsiku põhjapõdra nahale. Sarnaselt eelmiste lugudega oli taas tegemist keelust üleastumisega.

Ema hoiatas lapsi järmiste sõnadega:

Lapsukesed, lapsukesed, hoidke end, seal, kus kõrgub kivi, seal passib sind inimene, seal, kus on jäme känd, seal püüab teid inimene kinni.

Kümnes jutt (kokkuvõte vt 4.1.2.1.2)

Selles suhteliselt lühikeses kildini jutus leidub mitu omapärast joont. Tütar keelas vanematel panna asemenaha kuivama põhjapõdra käigurajale. Loos kõneldakse koja purustamisest, milles osalevad nii isa kui ka poeg ja millega seondub senise mikromaailma purunemine. Ema hoiatas poega: $M u$ poiss, sind ootab surm iga kivi juures.

Vanemad läksid pärast väimehe ja tütrepoja lahkumist korraks oma koju, kuid naasid peagi tütre juurde. Jutustaja lõpetab loo kogenud vestja sõnadega: Ma olin täna nende juures, nad olid meid külla kutsunud.

\section{Läheb edasi...}

Täiendav kirjandus

Briskin, N. 1917. Loparskije skazki. Arhangelsk (ilmunud ka Izvestija Arhangelskogo obshtshestva izutshenija Russkogo Severa 1, 1917, 1k 213--223).

Itkonen, T. I. 1945/1946. Suomen lappalaisten haltijausko. Kalevalaseuran vuosikirja 25/26, 1k 127-138.

Itkonen, T. I. 1960. Lapin noitien "kaksintaistelu" peuralaumasta. Kalevalaseuran vuosikirja 40, lk 82-133. 
Jermolov, A. 1959. Saamskije skazki. Murmansk.

Koskimies A. V., Itkonen T. I. 1978. Inarinlappalaista kansantietoutta. Toinen, uudistettu painos. Helsinki (Suomalais-ugrilaisen seuran toimituksia; 167).

Petruhhin, V. J. 1986. Tshelovek i zhivotnoje v mife i rituale: Mir prirodõ v simvolahh mira kulturõ. Mifõ, kultõ, obrjadõ narodov zarubezhnoi Azii. Moskva, lk 5-25.

Qvigstad, J. 1925. Lappische Märchen- und Sagenvarianten. Helsinki.

Tsharnoluski, V. V. 1966. O kulte Mjandasha. Skandinavski sbornik. Tallinn, lk. 301-315.

Thon'alunawe:

\section{Jooniste allkirjad}

Joonis 24. Karu. Pronksnaast Permi oblastist. IV-V sajand. Oborin \& Tshagin 1988: 75 järgi.

Joonis 25. Lindinimene teriomorfse peakatte ja tiibadega. Pronksnaast Permi oblastist. I-III sajand. Oborin \& Tshagin 1988: 60 järgi.

Joonis 26. Saam XVIII sajandi teisest poolest. Johann Gottlieb George koguteosest "Kõigi Vene riigi rahvaste kirjeldus". Kosmenko 1993: 13 järgi.

Joonis 27. "Perekonnaõnn" (V. Tsharnoluski järgi). Vanemad lapsega sisalikulaadsel olendil põdrapeadest võlvi all. Pronksnaast Permi oblastist. VIII-IX sajand. Oborin \& Tshagin 1988: 125 järgi.

Joonis 28. Luusse nikerdatud põhjapõdrakujutised. Kodalànyi 1975: 206 järgi.

\section{Kommentaar}

*22 Koannt-akka (saami 'põhjapõdraeit') - haldjas, kes hoolitses põhjapõtrade sigivuse ja jahitavuse eest. 